\title{
A space of European de-industrialisation in the late twentieth century: Nord/Pas-de-Calais, Wallonia and the Ruhrgebiet
}

\section{René Leboutte}

To cite this article: René Leboutte (2009) A space of European de-industrialisation in the late twentieth century: Nord/Pas-de-Calais, Wallonia and the Ruhrgebiet, European Review of History: Revue européenne d'histoire, 16:5, 755-770, DOI: 10.1080/13507480903262785

To link to this article: http://dx.doi.org/10.1080/13507480903262785

曲 Published online: 20 Oct 2009.

Submit your article to this journal $₫$

Џ Article views: 73

Q View related articles $₫$ 


\title{
A space of European de-industrialisation in the late twentieth century: Nord/Pas-de-Calais, Wallonia and the Ruhrgebiet
}

\author{
René Leboutte* \\ University of Luxembourg
}

(Received December 2008; final version received July 2009)

\begin{abstract}
This essay focuses on the major industrial changes from the late 1950s onwards in the industrial basins from the Nord/Pas-de-Calais to the Ruhrgebiet. The notion of industrial redeployment (reconversion industrielle) is critically analysed in the framework of European integration. The comparative approach highlights the importance of the timespace dimension which differs from one basin to the other. The diverse individual and collective actors also were in command of different power resources according to the various state traditions. The European Community, however, appears to have played an increasing role, culminating at the time of the steel industry crisis (1975-1985).
\end{abstract}

Keywords: de-industrialisation; European Coal and Steel Community; industrial basin; industrial redeployment; industrialization

Since the late 1950s, the process of de-industrialisation has deeply transformed Europe's societies and the European landscape. It has affected the regions of heavy industry in the heart of Western Europe, including Great Britain and numerous industrial basins from the region of Nord/Pas-de-Calais to the Ruhrgebiet. Beginning in the 1980s, the process of de-industrialisation became part of a more global phenomenon that was marked by the development of high technology, dematerialisation and an externalisation of production: in a word, the globalisation of the economy. ${ }^{1}$ The hypothesis of this article is that de-industrialisation is a regional and transnational process that has to be observed at multilevel stages (regional, national, transnational, continental and global). The national approach usually adopted by historians is not adequate in analysing the complexity of de-industrialisation and 'industrial reconversion' or 'industrial redeployment'. Indeed, the notion of reconversion itself has changed since the 1960s to encompass a broader and deeper change of society in the context of economic and social globalisation.

What does 'de-industrialisation' mean? Where and when does it take place? Who are the actors? How did the notion of 'reconversion' evolve to encompass the problems of the whole society? The present essay aims to provide some answers to these questions, and to contribute to the broader discussion concerning the structural economic and social changes, both at a micro- and macro-level, that have taken place since the 1970s.

\section{The concept of de-industrialisation}

The term de-industrialisation generally describes the shift from a society whose economy is based on heavy industry and the intensive use of non-renewable energy resources

*Email: rene.leboutte@uni.lu 
towards a society whose economy is increasingly influenced by a growing advanced tertiary sector. This said, even in the case of Europe it remains precarious to speak of 'post-industrial' societies. The historian of post-1945 European social and economic history has to recognise that industry has not disappeared, but rather has been deeply transformed by new technologies, new schemes of capital management, energy supply, and a new division of labour on a world scale (globalisation). When using the term de-industrialisation we are thus talking primarily about structural changes in the energy and heavy industry sectors; i.e. a reduction of coal mining, a decline of the textile industry, a restructuring of the steel and manufacturing industries, and a change in shipbuilding activities. Hence we are dealing much more with processes of 'industrial reconversion' rather than with industrial decline in a straightforward sense. ${ }^{2}$

Critically, the process of de-industrialisation predominantly affects local and regional (both transnational and sub-national) communities, called industrial areas or industrial basins. Heavy industry was originally located close to raw materials - especially coal and iron-ore resources - which then gave birth to industrial towns. Because such basins of resources form a natural chain which is in no way contingent on changing political national borders, the history of industrialisation/de-industrialisation is inherently a transnational, macro-regional one. ${ }^{3}$ The most impressive example in Europe is the chain of basins between the Pas-de-Calais and the Ruhrgebiet, running through 'the Nord' of France, Lorraine and Wallonia. These industrial basins are of different geographical size and each underwent the processes of industrialisation, urbanisation and population growth in different periods of time. Nevertheless, and despite being separated by political borders resulting from wars, these basins form a single huge industrial space in the heart of Europe, whose evolution has been influenced by the process of industrialisation (technological transfers and labour migration). These basins share similar patterns of industrialisation and de-industrialisation, the major common feature being that these processes are simultaneously regional and transnational rather than national. In that sense one could speak of a transnational industrial macro-region.

The historian, however, is confronted with a problem of sources when dealing with the regional and transnational nature of industrialisation and de-industrialisation, primarily the lack of other than centralised statistical data at the national level. The national administrations' perspective therefore conceals the regional and the transnational nature of these industrial areas. European integration has rebuilt the social, industrial and economic unity of a space dismantled by age-old national borders, however, through the European Coal and Steel community in the 1950s to the Common Market.

\section{Status quaestionis}

The question of how to define the space within which the processes of industrialisation/de-industrialisation occurred is a major challenge. The history of the Wallonian basins, the Ruhrgebiet and Nord/Pas-de-Calais shows that over the last two centuries the space has dramatically changed in terms of both size and structure. The borders of the industrial regions have shifted geographically according to the diverse phases of industrialisation. Consequently, it is virtually impossible to adopt a strict geographical delimitation - a fixed border, so to say - for the area. For this reason, it seems more appropriate to adopt the notion of gradients (Grenzraum rather than Grenzlinie) when speaking about the macro-region and to think of this complex of industrial basins as a space marked by expanding and contracting boundaries according to economic fluctuations. 
The spatial dimension, in particular the spatial 'flexibility' of industrialisation/deindustrialisation, was highlighted by Anthony Wrigley in his seminal work Industrial Growth and Population Change: A Regional Study of the Coalfield Areas of North-West Europe in the Late Nineteenth Century, published in 1961. ${ }^{4}$ The key word in the title is 'regional', which was new to historiography at the time. ${ }^{5}$ Wrigley convincingly argued that choosing a regional and transnational perspective was more appropriate to dealing with the problematic than the conventional approach, which used the framework of national history. Moreover, his work probably represents the first attempt at inquiring systematically into the process of industrialisation from a regional and transnational perspective by disaggregating national statistical data into regional series. As far as the delimitation of the coalfield areas of North-West Europe is concerned, A.E. Wrigley focused on the maximum expansion of the industrial macro-region, which coincided with the last stage of industrialisation in the 1950s and 1960s. Following Wrigley, Sidney Pollard subsequently launched an important debate on the regional dimension of industrialization. ${ }^{6}$ This debate surrounding the regional and transnational dimension of the early stages of industrialisation was reinforced by the controversy around the notion of proto-industrialisation coined by Franklin Mendels in the 1970s. For our purposes, the main conclusion of the debate is most relevant: the process of industrialisation has to be analysed on a regional level rather than on the level of nation-states (even if we recognise the important role of the state as an actor in that process). Similarly, Polish historians have drawn our attention to the fact that 'economic regions' are products of human activity. Once again, the regional and transnational nature of such constructions of space invites historians to overcome the traditional time-space framework, i.e. the conventional focus on the nation-state, the aggregation of statistical data into national series, and the chronology imposed by national political events. The same historians have addressed the theoretical and methodological challenges of defining an 'economic area', a question which remains highly controversial among geographers today. These scholars insist on the dynamic nature of region-building processes: According to them, an 'economic region' or 'area' is a system created by industrialists whose purpose is the optimal exploitation of resources and the optimal organisation of the industrial process. ${ }^{7}$

This transnational approach also underlines the importance of discontinuity not only in time but also in space. Joël Michel's monumental doctoral thesis, for example, is a strong substantiation of the power of a comparative transnational historical approach to the study of the working classes in the nineteenth century. ${ }^{8}$ Temporo-spatial continuity/ discontinuity is one of the main characteristics of the industrial regions under consideration. Industrialisation started earlier in 'the North' than in the Ruhr. Coal was exploited on a large scale as early as the seventeenth century in the basins of Liège and Charelroi, and in the late eighteenth century around Valenciennes, but only in the 1830s in the Ruhr valley. Moreover, the transfer of technology, labour, capital and management skills from Liège to the basins of Aachen and the Ruhr and from Charleroi and Borinage to the North of France during the nineteenth century highlights the vast impact of the early phase of industrialisation in Wallonia on the development of the broader region. ${ }^{9}$

The case of the Ruhrgebiet is probably the best example of the 'geographical' formation of a sub-national region. In the beginning the Ruhrgebiet had no tangible borders. Only slowly did the region as a geographical entity emerge through industrial expansion (from the heart of the Ruhr to the periphery) and through changing political and administrative borders. ${ }^{10}$ This is also true for Nord/Pas-de-Calais, a region which is still composed of different sub-regions (like the sub-regions of Lille dominated by the textile industry, Douai-Valenciennes with the steel industry, and the Bassin minier itself). 
The dramatic industrial change that occurred in the late 1960s, with the massive closure of collieries, the collapse of the textile industry and the restructuring of the steel industry, has recently drawn the attention of historians to the regional and transnational dimensions of the process. ${ }^{11}$ The question of the de-industrialisation of the Nord/Pas-deCalais and the Ruhrgebiet has been studied in an explicitly comparative perspective rather than as separate national phenomena. The results of this recent research have shown that the phenomenon of de-industrialisation is clearly a transnational one. At the same time, it has demonstrated that the process of industrial redeployment in each of the two basins followed quite different paths due to the fact that the respective national governments adopted different policies of redeployment. It is therefore only in a comparative and transnational perspective that the similarities and differences between regional developments can be adequately highlighted. ${ }^{12}$ Probably the best analysis of the dangers involved with adopting a too narrowly 'national' approach to the study of the processes of industrialisation/de-industrialisation can be found in Michel Quévit's comparison of Wallonia with other European industrial regions. ${ }^{13}$ Similarly, another recent comparative study explores how the urban network of coalmining towns forms a transnational space. ${ }^{14}$ At the same time, the vivid debate over the Italian 'industrial districts' has added another dimension which should be taken into account by transnational history: the regional networks of entrepreneurs, high-skilled handicraftsmen and entrepreneurial families involved in high-tech industrial production. Numerous monographs on the specificity of Northern Italy's industrial districts further highlight the need to examine the regional and, to some extent, the transnational dimensions of industrialisation and de-industrialisation rather than sticking to traditional national approaches to social and economic history. ${ }^{15}$

More recently, the notion of 'space' has been expanded to include both 'constructed space' and 'space construction as a mental process'; that is to say, a space which is a human construction for a specific objective (particularly in our case increased productivity) and a space which is also a 'mind space', a mental representation. This new approach fits well with the question of industrial areas/macro-regions (space) and de-industrialisation (time). ${ }^{16}$ The way in which the industrial basins have been named, for example, reveals how the space itself is culturally constructed. Usually, the names of the industrial basins originally came from topographical references (the Ruhrgebiet refers to the river Ruhr), historical settlements (the Borinage refers to a piece of land inhabited by the 'Borins'), or simply administrative divisions (Pas-de-Calais). Industrial development and the process of urbanisation, however, have since given birth to a consciousness of shared identity by the people living in the industrial basins. ${ }^{17}$

In identifying the whole chain of industrial basins from the Pas-de-Calais to the Ruhr, A.E. Wrigley used the designation Austrasian Coalfield, in reference to earlier names used for north-eastern regions of the Kingdom of the Merovingian Franks. Wrigley talked of 'Austrasian Coalfields' precisely in order to highlight the socioeconomic unity of one of the most important transnational industrial areas of Western Europe. As he himself noted, however, this unity should not be interpreted as implying uniformity: the industrial development of each of the 'Austrasian Coalfield' sub-regions followed a different trajectory, with public (i.e. national) authorities intervening at different times and in different ways (for instance, with national coalmining legislation based on a common source, the Napoleonic code, nationalisation of the coal industry as in Charbonnages de France, bilateral national agreements such as the Italo-Belgian agreement on labour migration in 1946, and so on).

The difficulty in naming such a complex of industrial areas is not just a challenge for historians but also for policy-makers. The moniker 'Austrasian Coalfields' was already 
used in the 1940s, in the context of discussions regarding the economic future of Europe. Etienne Hirsch, an economist who deeply influenced Jean Monnet in his ideas for creating a European industrial state after the Second World War, reported in his memoirs that he had met Monnet at Alger in 1943. Monnet talked about his vision of creating a European 'industrial state' comprising the Ruhr district, the Walloon basins, Lorraine and the Sarre. For Hirsch it seemed a utopian idea: could it be possible to 'rebuild the Lotharingia' after a millennium of sovereign states, he asked ${ }^{18}$ René Mayer, another close collaborator of Monnet's, was fascinated by Monnet's transnational vision, that the Ruhrgebiet and the other industrial regions in the vicinity should become the heart of a post-nationalistic Europe: the so-called 'industrial Lotharingia'. ${ }^{19}$ Interestingly enough, this name was used again in 1961 in an official report concerning the question of 'industrial reconversion'. ${ }^{20}$ If the historical reference to Lotharingia was meant to evoke the myth of a unified Europe it also highlighted a reality: the transnational unity of the industrial regions of Europe which had been artificially cut by military and political national borders. For people like Monnet, this is precisely one of the main objectives of the European Coal and Steel Community: to rebuild a common space artificially dismantled by war.

The 'Austrasian Coalfields' share common characteristics. They combine rural space (landscape) and urban space (townscape) without having a metropolis serving as a clearly marked geographical centre. Industrialisation in these regions took place a certain distance from - and more or less independent of - main cities like Lille, Mons, Liège or Düsseldorf. Instead, this industrialisation gave rise to new urban conglomerates that developed out of villages: Seraing, Lens, Dortmund, etc. The new urban network was based on a high density of industrial units, coal pits and housing areas. More recently, the process of de-industrialisation deeply challenged such organisation of the space and the society.

Within the huge region between the Pas-de-Calais and the Ruhr, exchanges and communication were always intense: technology was transferred from Wallonia to the basins of Aachen and of the Ruhr in the nineteenth century; Walloon contractors established factories in these same areas; coalminers migrated from Couchant-de-MonsBorinage to the Valenciennois; and capital flowed from Liège to Aachen and the Ruhr. However, in periods of industrial crisis nationalist attitudes prevailed and trans-border communication within the region decreased.

\section{The dimension of time}

The process of industrialisation deeply interfered with the traditional rural lifestyle and dramatically changed the landscape. Most notably, it gave birth to a working-class territory and community. During the early phase of industrialisation (1800-1860), the establishment of collieries and ironworks, the creation of new transportation networks and massive immigration of industrial workers thoroughly transformed rural society into an industrial one. The industrial regions usually emerged from entirely rural environments. They grew very quickly and without systematic planning, becoming 'hybrid scapes' characterised by a mixture of rural landscapes and industrial townscapes. According to the French geographer Demangeon, the coalfield of the Pas-de-Calais in the early twentieth century was just a piling up of villages overcrowded by proletarian workers. Vidal de la Blache, meanwhile, proffered that the accumulation of mine shafts, factories and houses was not enough to produce a townscape. Instead, this accumulation just provided the 'primary material for towns waiting to come to life'. ${ }^{21}$ The next phase of industrialisation (from around 1860 to 1960) was a time of intensive industrial development and 
urbanisation. It was the time of the prosperous heavy industry and of the "classical working class'. The industrial basins became the paradigm for economic power. They also became the foundation upon which the myth of working-class identity was forged. This myth was deeply rooted in both regional and transnational space through the 'tradition' of the international working class.

After more than a century of industrial expansion, the 1970s and 1980s were marked by a total rupture. The decline, and partial disappearance, of heavy industry (especially collieries and manufacturing units) affected all the regions thus far discussed. The process of de-industrialisation eliminated many of the structures that had integrated the region in the past. Sub-regions, like the Nord/Pas-de-Calais or the Ruhrgebiet, that had emerged over the course of industrialisation ceased to provide a territorial basis for 'sustainable development'. Old industries - including textile manufacturing - disappeared, with new and totally different industrial activities - for example automobile manufacturing - and high-tech services and education institutions (universities) taking their place. Although closely accompanied and heavily funded by national governments, these structural changes were both a regional and a transnational phenomenon. This reality was explicitly recognised by the European Community, as seen in its numerous surveys on industrial redeployment from 1960 to1980.

Of course, in the industrial space from the Pas-de-Calais to the Ruhrgebiet, the processes of de-industrialisation followed different chronologies in different sub-regions. The overall process started in the 1950s in the oldest industrialised regions, especially in the Borinage (Wallonia) where the obsolete collieries had to be closed down due to pressure from the European Coal and Steel Community (ECSC). In general, however, the process of de-industrialisation accelerated first in the early 1970s, when it became a major transnational phenomenon. At that time, the process involved three levels of decisionmaking: the transnational region (which was increasingly recognised as a valid field of action), the respective nation-states and the ECSC. Transnational action played a particularly major role in this process, as the closure of obsolete collieries and ironworks was dictated by the accelerating processes of globalisation, a newly emerging international division of labour, and the effects of the end of the Fordist era. This is precisely why, in view of transnational structural changes, the ECSC had to intervene alongside the nation-states.

Essentially, since the late 1960s there has been an inversion of the tandem relationship between urbanisation and industrialisation. Previously, industry was the key element around which urbanisation was organised. Now, new high-tech industries are independent of the pre-existence of well-functioning metropolises. Therefore, the majority of industrial basins with their decaying urban centres have turned into depressed areas. This is why industrial redeployment was, and still is, so difficult. ${ }^{22}$ The question becomes, what can be done in order to transform old industrial areas (in the jargon of the European Community: Régions Europénnes de tradition industrielle - RETI; i.e. European areas of industrial tradition) into pioneering regions meeting the criteria of sustainable development and the requirements for promoting a 'society of knowledge'? These are the challenges of the reconversion process.

The complex of basins under consideration was and still is a space of intense labour migration. Cross-border migration and transnational immigration have a long history in this part of Western Europe (seasonal workers, cross-border migrant workers, etc.) that goes back to the eighteenth century. Today, however, such transnational migration has greatly intensified, generating new transnational social networks. The interregional and transnational movement of workers has contributed to the creation of a transnational 
culture and transnational mindscape not only in the Grande Région (Luxembourg, Lorraine, Wallonie, Sarre), but also across the border between Nord/Pas-de-Calais and Wallonia as well as in the Euregio Meuse-Rhin.

\section{'Industrial reconversion': a (macro-)regional phenomenon to be analysed in a transnational perspective}

Processes that seemed necessary for the advancement of technical innovation, the modernisation of companies (collieries, iron and steel units), and government-funded professional training for unskilled workers (réadaptation) were originally discussed by political actors using the term 'industrial reconversion'. The label was used by Jean Monnet and Robert Schuman in $1950 .^{23}$

As we shall show, the meaning of the term has changed over time. It is particularly interesting, however, that the term 'reconversion' is very difficult to translate. In English, the appropriate word is 'industrial redeployment', in German 'Strukturwandel'. The French word has its own history. French authorities made a subtle distinction between 'conversion' and 'reconversion'. Conversion was linked to the problems of territorial planning (aménagement du territoire). Evidence for this is provided by Olivier Dard. In 1966, the institution DATAR (Délégation à l'aménagement du territoire et à l'action régionale) expressed concern about the future of the collieries of the Pas-de-Calais. According to the DATAR, the challenge was not to 'convertir une entreprise' (industrial redeployment) but to 'convertir une région' (restructure a region). In the same year, special institutions were created in the Lorraine and the Nord/Pas-de-Calais: the 'bureaux d'expansion et de conversion industrielles'. The term 'reconversion' seems to have been introduced somewhat later - in the 1970s and 1980s - and referred to the closure of obsolete industrial units and the process of attracting new industrial activities like car manufacturing. In November 1974, the Comité interministériel d'aménagement des structures industrielles was established in France to handle the process of de-industrialisation from the top (the government). ${ }^{24}$

The context (and also the meaning) of Strukturwandel was different in the Ruhrgebiet. The regional authorities rather than the federal government were the actors and decision-makers. ${ }^{25}$

In the context of European Community politics, the meaning attributed to the idea of reconversion (and also to the practices involved) once again changed dramatically. In the early days of the ECSC, the opening of a common market was seen as an instrument for the implementation of a new division of labour in Europe. Temporary social measures seemed necessary to compensate for unemployment which resulted from the closure of obsolete collieries and ironworks. European support for technological innovation and professional training was initially a transitional measure based on joint national funding.

The coal crisis of the late 1950s and early 1960s, however, dramatically changed the paradigm of industrial reconversion. ECSC reports dealing with the industrial basins of the Nord/Pas-de-Calais, Wallonia, Ruhrgebiet and Sarre-Lorraine-Luxembourg identified a new challenge: the economic and social rescue of these regions. The drama of the coalmining crisis of 1958-1959 led ECSC experts to become aware of the fact that economic development in these regions could only gain momentum if industrial (technological) modernisation was accelerated and investment in the training of skilled workers was stepped up. 'Industrial reconversion' thus acquired the status of a long-term programme meant to imbue regional development with new social and economic dynamics. 
The 'discovery' that industrial areas consisted of complex communities with long social and cultural traditions (and not simply of spaces overcrowded with anonymous proletarians) served as the impetus for the European regional policy of 1966. Industrial areas from the Pas-de-Calais to the Ruhrgebiet were engaged in this regional policy, although in different ways, according to the national context. The historiography of European integration has highlighted how Community policies (especially regional policies and the common agricultural policy) encouraged the process of regionalisation and transnational regional cooperation. Europe as such is 'a factor favouring regionalisation' (to use a term coined by Helena Madurowicz-Urbanska). ${ }^{26}$

The process of regional redeployment has its own history, as the industrial regions under consideration demonstrate. The first operations of reconversion simply consisted in cleaning the ground of obsolete industrial units. The idea was to implement change abruptly and radically, both in real terms and in terms of the public image of the area. The hope was to make the region attractive again - particularly to multinational corporations - by offering favourable conditions for new industrial investments. The assumption was that it would be impossible to install new, 'clean' activities in the middle of ruins. Subsequently, it became important to 'erase' the region's 'embarrassing past': trade-union struggles, working-class self-government, a decaying and unhealthy habitat, the depressing social climate, etc. Such policies of 'cleaning' the space were certainly necessary to some degree, and in some cases even succeeded.

Nevertheless, this essentially negative approach to reconversion provoked reactions from both the population (in the form of strikes and regional working-class identity activism) and from academics who protested against the systematic deconstruction of a collective memory, such as through the demolition of historical buildings and a rejection of the region's industrial heritage. During this time (1975-1985) industrial archaeology flourished as a new field of historical research: industrial museums were created, industrial landscapes were preserved, and archival materials documenting the industrial history of the region became a public concern. In 1983, for instance, the Centre des Archives du monde du travail was established at Roubaix. Similar initiatives, some of them rather spectacular, were adopted in the Ruhr (such as the Deutsches Bergbau-Museum in Bochum). As we can see, from the Pas-de-Calais to the Ruhrgebiet similar collective reactions to de-industrialisation occurred: across the region, society reacted to the realities of economic transformation by vehemently defending its identity, which had been forged during the time of industrialisation. At the same time, of course, there was the widespread pessimistic feeling in the 1980 s that the region had 'no future'.

One of the major challenges, in economic terms, was to transform these industrial regions through higher education into regions able to compete with nearby metropolises. The creation of the University of Bochum and the University of Artois provides two major examples of this development. ${ }^{27}$

\section{From de-industrialisation to regional planning and sustainable development}

Following the implementation of the single European Act in July 1987, the European Community increased the funds for industrial redeployment. 'Objective 2' focused on the old industrial regions that were most seriously affected by industrial decline. ${ }^{28}$ At that time, two concepts were introduced: 'sustainable development' and 'governance'.

The concept of sustainable development, which first appeared in 1987, is now one of the main criteria for the management of industrial reconversion. This principle, of course, is quite different from the one which drove industrialisation in the macro-region's early 
history, namely the intensive exploitation of non-renewable resources and the optimisation of the means of production. The challenge of reconversion has thus become to precisely define and implement alternative paths of social and economic development for the old industrial basins. ${ }^{29}$ This is why the question of collective identity, collective memory and industrial heritage are as crucial as innovation.

\section{Governance: the actors}

The history of reconversion since the early 1960s reveals how the process has required a 'multilevel' approach to joint governance by the European Union, nation-states, regional administrations (Länder), and local communities. In view of the transnational character of reconversion, it became clear that shared governance through agents on the different levels was necessary. Occasionally the term 'territorial governance' has been used in this context, in order to account for the fact that these pilot areas represent regions that transcend the borders of nation-states as well as of sub-national administrative units.

In France and Belgium, the key actor remained the central state, at least until the 1980s. In France, the DATAR and Charbonnages de France (a nationalised company) under the close control of the state (Ministère de l'Industrie, Commissariat au Plan) were the principle actors of reconversion. In the Ruhrgebiet, meanwhile, the main actors were the Land and sub-regional (inter-communal) institutions, such as the Siedlungsverband Ruhrkohlenbezirk (1920), which became the Kommunalverband Ruhrgebiet in 1987. In Belgium the longstanding tension between the Flemish and the Walloon communities made the decision-making process even more complicated.

Trade Unions too played an important role, although once again the situation largely differed among France, Wallonia and the Ruhrgebiet. In the Nord/Pas-de-Calais, where political power at the regional level was in the hands of the Communist Party, strikes in favour of maintaining companies and of securing employment at all costs were frequent. In the Ruhrgebiet, the trade unions instead favoured joint action by employers, state agencies and workers to promote long-term reconversion. ${ }^{30}$

The process of industrial redeployment from the late 1960s onwards involved not only regional authorities but also nation-states and the EU Commission. Interventions in one region, such as in the Nord/Pas-de-Calais, appear to have had immediate impact on other industrial regions. New networks of transportation (high-speed trains, motorways) led to transnational regional cooperation. Similarly, the foundation of new universities in these regions had a positive impact on the industrial basin as a whole.

The actors at each of the different levels had little choice but to cooperate. Transnational regional cooperation generated 'Euro-regions', such as Euregio MeuseRhin and Euregio SaarLorLuxRhin.

Multinational companies also played a crucial role in strengthening transnational cooperation throughout the macro-region. However, during the industrial crisis of the mid1970s, individual nation-states spontaneously imposed measures aimed at safeguarding 'national interests'. Governmental intervention provided benefits for 'national champions' by offering guaranteed state credits to companies and by supporting company mergers. Such policies of 'national priorities', however, proved ineffective due to the transnational character of the steel industry. The result of these measures was overproduction, which in turn led to the European Commission being forced to impose production quotas and to implement other measures to rationalise the sector. In the meantime, a process of transnational merging took place which led to the emergence of international steel companies like Arcelor (and more recently Arcelor-Mittal). Economic integration at the 
regional level thus had a significant effect on interregional and transnational economic spaces. The European Community (the Commission) became a key actor. The necessity of having to cope with the problem of reconversion opened up new opportunities for nationstates to reaffirm their sovereignty. In 1959, the High Authority of the ECSC tried to impose a European plan for the rescue of the coalmining districts, specifically the Walloon collieries. The Germans and, even more vehemently, the French refused to provide the High Authority with the necessary extended authority to implement supra-national decision-making. In France, this decision was taken at the governmental level based on the Jean-Marcel Jeanneney Plan (1960-1965). Within the framework of European institutions like the European Coal and Steel Community and the European Economic Community, nation-states have always maintained their sovereignty in decisions concerning economic matters which they considered to be in their 'national interest', even in situations where national decisions involved the risk of creating major obstacles to overall European integration. As an example, in 1959/1960, France- quite successfully - maintained its national position in a controversy with the Haute Autorité de la CECA over a European plan for the conversion of the European coal mining industry. ${ }^{31}$ This 'national success' represented a disaster for the High Authority of the ECSC, which was then forced to withdraw its own project. ${ }^{32}$ The lack of transnational European cooperation became even more acute during the crisis of the iron and steel industry of 1974-1985, when an almost suicidal policy of safeguarding 'national interests' at all costs prevailed. Each country imposed its own plan for the steel industry without considering the strategies of its immediate neighbours, let alone possibilities for joint European action. In 1976, the French produced the 'Plan acier' in order to save the steel industry of the Nord/Pas-de-Calais by making the new Usinor a 'national champion'. Belgium acted in a similar way, although the political conflict between Flanders and Wallonia led to a more complicated course of action: the creation of the company Cockerill-Sambre, a very weak conglomerate of various production units in the early 1980. Such nationalistic and short-sighted action worsened the crisis to a point where, in 1979, the European steel industry was close to total collapse. The European Commission then decided to intervene by imposing a plan for the reduction of production and for modernisation (the Davignon Plan of 1980). In many ways, this plan can be considered a successful attempt at managing the process of industrial redeployment at the Community level. ${ }^{33}$

Another major actor of the regional redeployment has been and still is the European Investment Bank. ${ }^{34}$ The EIB archives show how this institution has become more and more involved in 'reconversion programmes' and transnational economic development. EIB financial support for the Our hydroelectric power station in Luxembourg starting as early as 1958 demonstrates the larger, transnational objectives of the project itself, namely the establishment of a European, transnational connection among the electric networks of Luxembourg, France (Lorraine), Sarre, Wallonia and the Ruhrgebiet. The archival materials show the degree to which there was a willingness to overcome national boundaries to create a European space of industrial regions. Consequently, in this as well as in many others cases, the historian has to adopt a multilevel approach - macro-regional, national and European - to correctly understand the driving force behind such a European institution. And this case is not unique. ${ }^{35}$

\section{Conclusions}

The history of industrial reconversion in North Western Europe during the second half of the twentieth century is a field of research that allows for raising, in an exemplary way, 
the question of how to conceptualise historical space. The profound transformation of the industrial sector which began in the 1950s, and continues to this day, is a macro-regional, transnational phenomenon with rather clear geographical demarcations. It comprises the chain of traditional basins of heavy industry situated in the border areas of France, Belgium, Luxemburg and Germany. Many different actors are involved in the complex processes of coping with the challenges of industrial reconversion: supra-national companies, national governments and regional administrations, inter-governmental bodies and EU institutions, and not least the representatives of local and regional populations. Their respective activities translate into structural change at different levels: local, regional and macro-regional - with the nation-states still playing a significant role.

Basically, the transformation of this industrial landscape was the result of global rather than regional developments. The rise of new centres of steel production (namely Japan in the 1960s), the re-shaping of the energy sector (the decline of coalmining due to competition from the oil industry and nuclear energy), the emergence of new providers for raw materials (iron ore), and, not least, the dramatic development of new technologies have all fundamentally undermined the economic status of the former pioneering region of European industry. Globalisation is not just a word 'à la mode': it is a major transformation process in which societies traditionally assimilated to 'national identity' tend to become increasingly orientated towards shared experiences and joint interests in a regional (whether sub-national or transnational) context, and to redefine their loyalties and political agendas accordingly. In that sense, 'reconversion' brings in a new, and wider, dimension: How to cope with structural and global changes at a macro-regional level? This is a challenge for European institutions, but also for historians who have to adopt a multilevel approach to their a work, a difficult exercise not only in terms of academic background (national histories) but also because the sources, i.e. documents, are still collected and organised within a national framework.

In particular, historians have to account for the fact that transnational industrial areas are not only spaces of macro-regional interaction and communication but, at the same time, also of global transformation, national and transnational policy-making as well as of sub-regional and local activity. We should therefore adopt a double perspective: Historians have to inquire, on the one hand, into how economic macro-regions emerged, and were transformed, under the impact of broader economic developments as well as of intra-regional communication, transfers, migration, policy-making etc. On the other hand, they have to study regional phenomena in a thoroughly comparative perspective - in order to establish more precisely how developments on different spatial levels (global, European, national, regional) were interrelated in bringing about regional economic and political realities.

In any case, the study of the process of European integration can help historians to transcend the national paradigm in their approaches to their subject - even if the phenomena under examination (industrial reconversion in this case) are, to a significant extent, determined by national contexts and pressures.

\section{Notes}

1. Berend Ivan T. An Economic History of Twentieth-Century Europe. Cambridge: Cambridge University Press, 2006.

2. Debeir Jean-Claude, Jean-Paul Deléage, and Hémery Daniel. Les servitudes de la puissance. Une histoire de l'énergie. Paris: Flammarion, 1992.

3. Leboutte, René, "Coal Basins." In The Oxford Encyclopedia of Economic History, Editor in Chief Joel Mokyr, vol. 1, 455-9. Oxford: Oxford University Press, 2003. 
4. Wrigley, E.A. Industrial Growth and Population Change: A Regional Study of the Coalfield Areas of North-West Europe in the Late Nineteenth Century. New York: Cambridge University Press, 1961.

5. Goran, Ohlin. "Review of Industrial Growth and Population Change: A Regional Study of the Coalfield Areas of Northwest Europe in the Later Nineteenth Century, by E. A. Wrigley." Journal of Economic History 22, no. 3 (1962), 416-19.

6. Pollard, Sidney, ed. Region und Industrialisierung. Studien zur Rolle der Region in der Wirtschaftsgechichte der letzten zwei Jahrhunderte. Göttingen, Vandenhoeck \& Ruprecht, 1980. Pollard, Sidney. Peaceful conquest: The industrialization of Europe, 1760-1970. Oxford, 1981.

7. Dumolard, P. "Région et régionalisation: une approche systémique." L'Espace géographique no. 2 (1975): 93-111; Madurowicz-Urbanska Helena. "Aspects of micro- and macroanalysis in hitorical socio-economic regionalization." Studia Historiae Oeconomicae 13 (1978): 26-39; eadem, "Remarques sur la méthodologie des régions économiques et leurs valeurs épistémologiques." Studia Historiae Oeconomicae 15 (1980 [1981]): 87-93.

8. Michel, Joël. "Le mouvement ouvrier chez les mineurs d'Europe occidentale (GrandeBretagne, Belgique, France, Allemagne). Etude comparative des années 1880 à 1914." Thèse de doctorat d'Etat, Université de Lyon II, 1987.

9. Leboutte, René. "Intensive Energy Use in Early Modern Industrial Europe $\left(17^{\text {th }}-\right.$ early $19^{\text {th }}$ Century)." Istituto Internazionale di Storia Economica F. Datini, Prato, Serie II - Atti delle Settimane di Studi. Economia e Energia secc. XIII-XVIII, XXXIV Settimana di Studi Il Datini, a cura di Simonetta Cavaciocchi, 547-75. Firenze-Prato: Le Monnier, Prato, 2003.

10. Steinberg, Heinz Günter. "Das Ruhrgebiet im 19. und 20. Jahrhundert. Ein Verdichtungsraum im Wandel.” In Selbstverlag der Geographischen Kommission für Westfalen. Münster, 1985.

11. Leboutte, René. Vie et mort des bassins industriels en Europe, 1750-2000. Paris: L'Harmattan, 1997. Labasse, Jean. L'Europe des régions. Paris; Flammarion, 1991. Sabel, Charles F. "La riscoperta delle economie regionali." Meridiana 3 (1988): 13-71. Wodz, Jacek. Haute-Silésie. L'espace déchiré. Spécificité d'une région fort industrialisée. Katowice, 1990.

12. Three conferences have highlighted the superiority of the comparative approach concerning the questions of industrial regions, de-industrialisation and the industrial redeployment (reconversion industrielle in French): Berger François, Jean-François Eck, Peter Friedemann, and Karl Lauschke, eds. "Strukturwandel aus vergleichender regionaler Perspektive nach 1945: Ruhrgebiet und Nord/Pas-de-Calais." Mitteilungsblatt des Instituts für soziale Bewegungen 30 [Bochum, (2003); Eck, Jean-François, Peter Friedemann, and Karl Lauschke, eds. La reconversion des bassins charbonniers. Une comparaison interrégionale entre la Ruhr et le Nord/Pas-de-Calais, Revue du Nord, hors série. Collection Histoire n ${ }^{\circ} 21$. Lille, 2006; Tenfelde, Klaus, ed. "Raumbildung als mentaler Prozess: Schwerindustrielle Ballungsregionen im Vergleich." Mitteilungsblatt des Instituts für soziale Bewegungen 39 (2008).

13. Quévit, Michel. Les causes du déclin wallon. Brussels: EVO. 1978; Idem. La Wallonie, l'indispensable autonomie. Paris: Editions Entente, 1982.

14. Naissance et développement des villes minières en Europe, Etudes réunies par Jean-Pierre Poussou et Alain Lottin. Arras: Artois Presses Université, Collection 'Histoire', 2004.

15. Pyke, Frank, Giacomo Becattini, and Werner Sengenberger, eds. Distretti industriali e cooperazione fra imprese in Italia. Firenze: Banca Toscana, 1991; Giacomo Becattini et al. From Industrial Districts to Local Development: An Itinerary of Research. Northhampton, MA: Edward Elgar, 2003. Mirri, Mario. "Formazione di una regione economica. Ipotesi sulla Toscana, sul Veneto, sulla Lombardia." Studi veneziani XI (1986): 47-59.

16. Leboutte, René. "Space Construction as Mental Process: Heavy Industrial Regions in Comparative Perspective." In "Raumbildung als mentaler Prozess: Schwerindustrielle Ballungsregionen im Vergleich," ed. Klaus Tenfelde. Mitteilungsblatt des Instituts für soziale Bewegungen 39 (2008): 99-112.

17. Falter, Helmut, Dagmar Gassdorf, Jürgen Lodemann, Peter Krauskopf, and Karl Janssen. Vom Kohlenpott zur Metropole Ruhr. Edition Rainruhr, 2007.

18. 'Me montrant la région de la Ruhr et de la Lorraine, il m'explique que de là venait tout le danger. C'était grâce aux productions de charbon et d'acier que l'Allemagne et la France forgeaient les instruments de la guerre. Pour empêcher un nouveau conflit, il fallait, sous une forme ou sous une autre, soustraire cette région aux deux pays qui, par trois fois en moins d'un siècle, s'étaient affrontés. Nous discutâmes longtemps. Pour ma part, j'estimais utopique l'idée 
que l'on pourrait arracher de tels territoires, sources de tant de richesses, à des pays souverains et, après plus de mille ans, reconstituer la Lotharingie. Il fallait trouver autre chose.' Hirsch, Et. Ainsi va la vie, 78-79. Lausanne, 1988.

19. Mayer, September 1943. In Bossuat, G. D’Alger à Rome (1943-1957). Choix de documents, 47-54. Louvain-la-neuve, 1989.

20. Weiller, J. "La politique française de conversion, l'Europe des Six et ses engagements internationaux: l'exemple français." Problèmes de conversion économique. Analyses théoriques et études appliquées. Actes du Quatrième Colloque de l'Association de Science Régionale de Langue Française, Liège, mai 1964, 210-11. Paris: M.-Th. Génin, 1965.

21. Quoted by Joël Michel in Le mouvement ouvrier chez les mineurs d'Europe occidentale, vol. I, 96.

22. Merenne-Schoumaker, Bernadette. La localisation des industries, 171-6. Paris: Nathan, 1991.

23. Leboutte, René. "Le rôle de la Communauté Européenne du Charbon et de l'Acier le développement des politiques de reconversion industrielle et d'essor économique regional." In "Strukturwandel aus vergleichender regionaler Perspektive nach 1945: Ruhrgebiet und Nord/Pas-de-Calais," ed. François Berger, Jean-François Eck, Peter Friedemann, and Karl Lauschke, 33-42 Mitteilungsblatt des Instituts für soziale Bewegungen 30 (2003).

24. Dard, Olivier. "Les institutions publiques françaises d'aménagement du territoire et la reconverion des bassins charbonniers." In La reconversion des bassins charbonniers. Une comparaison interrégionale entre la Ruhr et le Nord/Pas-de-Calais, Revue du Nord, hors série, ed. Jean-François Eck, Peter Friedemann, and Karl Lauschke, 139-53. Collection Histoire $n^{\circ}$ 21. Lille, 2006.

25. Goch, Stefan. "Sind Kommunalpolitiker Betonköpfe? Handlungsspielräume der Kommunalpolitik im Strukturwandel des Ruhrgebiet." In La reconversion des bassins charbonniers. Une comparaison interrégionale entre la Ruhr et le Nord/Pas-de-Calais, Revue du Nord, hors série, ed. Jean-François Eck, Peter Friedemann, and Karl Lauschke, hors série, 107-12. Collection Histoire $n^{\circ} 21$, Lille, 2006; à propos des approches différentes de la reconversion, voir: Subra, Philippe. "La reconversion des régions industrielles, une approche géopolitique: l'exemple du Valenciennois." In La reconversion des bassins charbonniers. Une comparaison interrégionale entre la Ruhr et le Nord/Pas-de-Calais, Revue du Nord, hors série, ed. JeanFrançois Eck, Peter Friedemann, and Karl Lauschke, 125-37. Collection Histoire $n^{\circ} 21$. Lille, 2006.

26. Bitsch, Marie-Thérèse, ed. Le fait régional et la construction européenne. Bruxelles: Bruylant, 2003. Facteur régionogène: Madurowicz-Urbanska Helena. "Remarques sur la méthodologie des régions économiques et leurs valeurs épistémologiques." Studia historiae oeconomicae UAM 15, (1980): 87-93, 89.

27. Tenfelde, Klaus. "Raumbildung als ökonomischer, sozialer und mentaler Process." In Tenfelde, ed., Raumbildung als mentaler Prozess, op. cit., 5-19; Eck, Jean-François. "Die Entwicklung der Mentalitäten im nordfranzösischen Montanrevier während des 20. Jahrhunderts." In Tenfelde, ed., Raumbildung als mentaler Prozess, op. cit., 67-75.

28. Commission des Communautés européennes, Vade-mecum sur la réforme des fonds structurels communautaires, 14. Luxembourg: OPOCE, 1989.

29. Zuindeau, Bertrand. "Région Nord Pas de Calais, 2004, Atlas régional du développement durable Nord-Pas de Calais, La Tour d'Aigues, éditions de l'aube." Développement durable et territoire, Publications de 2004, mis en ligne le 20 novembre 2004. http://developpementdurable. revues.org/document1245.html (accessed September 11, 2008).

30. Subra, op. cit., 125-37; Kourchid, Olivier. "L'action syndicale minière entre l'économie et le politique: le cas de la récession en France et le Nord/Pas-de-Calais, 1956-2004." In La reconversion des bassins charbonniers. Une comparaison interrégionale entre la Ruhr et le Nord/Pas-de-Calais, Revue du Nord, hors série, ed. Jean-François Eck, Peter Friedemann, and Karl Lauschke, 189-222. Collection Histoire n ${ }^{\circ}$ 21. Lille, 2006; Schirmann, Sylvain. "La CFTD face aux reconversions industrielles de 1964 à 1978," in ibid., 223-33.

31. Kocher-Marboeuf Eric. "Jean-Marcel Jeanneney et la reconversion des bassins charbonniers." In La reconversion des bassins charbonniers. Une comparaison interrégionale entre la Ruhr et le Nord/Pas-de-Calais, Revue du Nord, hors série, ed. Jean-François Eck, Peter Friedemann, and Karl Lauschke, 29-42. Collection Histoire n 21. Lille, 2006.

32. Ibid. 
33. Leboutte, René. "La sidérurgie belge entre groupes financiers, pouvoirs publics et Commission européenne, 1960-2004." In Industrie et politique en Europe occidentale et aux Etats-Unis (XIXe-XXe sicèles), ed. Dominique Barjot, Olivier Dard, Jean Garrigues, Didier Musiedlak, and Eric Anceau, 225-42. Paris: Presses universitaires Paris Sorbonne, 2006; Leboutte, René. Histoire économique et sociale de la construction européennes, 453-500 (Peter Lang Collection Europe plurielle - Multiple Europes). Brussels: P.I.E.-Peter Lang, 2008. Berger, Françoise. "La gestion de la crise la sidérurgie. Le cas du Nord/Pas-de-Calais et du groupe Usinor." In La reconversion des bassins charbonniers. Une comparaison interrégionale entre la Ruhr et le Nord/Pas-de-Calais, Revue du Nord, hors série, ed. Jean-François Eck, Peter Friedemann, and Karl Lauschke,, 43-61. Collection Histoire ${ }^{\circ}{ }^{21}$. Lille, 2006; Lauschke, Karl. "Das Krisenmanagement der Stahlindustrie. Staat und Kozerne im Ruhrgebiet," in ibid., $63-79$.

34. Willaert, Emilie. "Les activités de la BEI l'Europe des Six (1958-1972)." In La BEI, 1958-2008, direction Eric Bussière, Michel Dumoulin, and Emilie Willaert, 51-70. Luxembourg: La banque de l'Union européenne, 2008.

35. Leboutte, René. "La BEI et le barrage hydroélectrique de l'Our: projet transfrontalier et ambitions européennes" (work in progress based on the archives of the EIB, Historical Archives of the EU, EUI, Florence).

\section{Notes on contributor}

René Leboutte is Jean Monnet Professor of Contemporary European History at the University of Luxembourg. He is a graduate of the University of Liège (PhD) and of the University of Lille III (Habilitation). He is a former Jean Monnet chairholder at the University of Aberdeen and former Professor in Social and Economic History at the European University Institute. His recent publications include: Histoire économique et sociale de la construction européenne (Brussels: P.I.E.-Peter Lang, 2008).

\section{Bibliography}

Becattini, Giacomo, ed. From Industrial Districts to Local Development: An Itinerary of Research. Northhampton, MA: Edward Elgar, 2003.

Berend, Ivan T. An Economic History of Twentieth-Century Europe. Cambridge: Cambridge University Press, 2006.

Berger, François, Jean-François Eck, Peter Friedemann, and Karl Lauschke, eds. "Strukturwandel aus vergleichender regionaler Perspektive nach 1945: Ruhrgebiet und Nord/Pas-de-Calais." In Mitteilungsblatt des Instituts für soziale Bewegungen. 30 Bochum, 2003.

Berger, Françoise. "La gestion de la crise dans la sidérurgie. Le cas du Nord/Pas-de-Calais et du groupe Usinor." In La reconversion des bassins charbonniers. Une comparaison interrégionale entre la Ruhr et le Nord/Pas-de-Calais, edited by Jean-François Eck, Peter Friedemann, and Karl Lauschke. Revue du Nord, hors série, 43-61. Collection Histoire no. 21, Lille, 2006.

Bitsch, Marie-Thérèse, ed. Le fait régional et la construction européenne. Bruxelles: Bruylant, 2003.

Bossuat, Gérard. D’Alger à Rome (1943-1957). Choix de documents. Louvain-la-neuve, 1989.

Dard, Olivier. "Les institutions publiques françaises d'aménagement du territoire et la reconverion des bassins charbonniers." In La reconversion des bassins charbonniers. Une comparaison interrégionale entre la Ruhr et le Nord/Pas-de-Calais, edited by Jean-François Eck, Peter Friedemann, and Karl Lauschke, Revue du Nord, hors série, 139-53. Collection Histoire no. 21, Lille, 2006.

Debeir, Jean-Claude, Jean-Paul Deléage, and Daniel Hémery. Les servitudes de la puissance. Une histoire de l'énergie. Paris: Flammarion, 1992.

Eck, Jean-François, Peter Friedemann, and Karl Lauschke, eds. La reconversion des bassins charbonniers. Une comparaison interrégionale entre la Ruhr et le Nord/Pas-de-Calais, Revue $d u$ Nord, hors série. Collection Histoire no. 21, Lille, 2006.

Falter, Helmut, Dagmar Gassdorf, Jürgen Lodemann, Peter Krauskopf, and Karl Janssen. Vom Kohlenpott zur Metropole Ruhr. Edition Rainruhr, 2007.

Goch, Stefan. "Sind Kommunalpolitiker Betonköpfe? Handlungsspielräume der Kommunalpolitik im Strukturwandel des Ruhrgebiet." In La reconversion des bassins charbonniers. Une comparaison interrégionale entre la Ruhr et le Nord/Pas-de-Calais, edited by Jean-François 
Eck, Peter Friedemann, and Karl Lauschke, Revue du Nord, hors série, 107-24. Collection Histoire no. 21, Lille, 2006.

Hirsch, Etienne. Ainsi va la vie. Lausanne, 1988.

Kocher-Marboeuf, Eric. "Jean-Marcel Jeanneney et la reconversion des bassins charbonniers." In La reconversion des bassins charbonniers. Une comparaison interrégionale entre la Ruhr et le Nord/Pas-de-Calais, edited by Jean-François Eck, Peter Friedemann, and Karl Lauschke. Revue du Nord, hors série, 29-42. Collection Histoire no. 21, Lille, 2006.

Kourchid, Olivier. "L'action syndicale minière entre l'économie et le politique: le cas de la récession en France et dans le Nord/Pas-de-Calais, 1956-2004." In La reconversion des bassins charbonniers. Une comparaison interrégionale entre la Ruhr et le Nord/Pas-de-Calais, edited by Jean-François Eck, Peter Friedemann, and Karl Lauschke, Revue du Nord, hors série, 189-222. Collection Histoire no 21, Lille, 2006.

Labasse, Jean. L'Europe des régions. Paris: Flammarion, 1991.

Lauschke, Karl. "Das Krisenmanagement der Stahlindustrie. Staat und Kozerne im Ruhrgebiet." In La reconversion des bassins charbonniers. Une comparaison interrégionale entre la Ruhr et le Nord/Pas-de-Calais, edited by Jean-François Eck, Peter Friedemann, and Karl Lauschke, Revue du Nord, hors série, 63-79. Collection Histoire no. 21, Lille, 2006.

Leboutte, René. "Coal Basins." In The Oxford Encyclopedia of Economic History, edited by Joel Mokyr, 455-9, Vol. 1, Oxford University Press, 2003.

Vie et mort des bassins industriels en Europe, 1750-2000. Paris: L'Harmattan, 1997.

. "Intensive Energy Use in Early Modern Industrial Europe (17th-early 19th Century)." In Istituto Internazionale di Storia Economica F. Datini, Prato, Serie II-Atti delle Settimane di Studi, Economia e Energia secc. XIII-XVIII, XXXIV Settimana di Studi Il Datini, edited by Simonetta Cavaciocchi, Firenze-Prato, and Le Monnier, 547-75. Prato: 2003.

— . "La sidérurgie belge entre groupes financiers, pouvoirs publics et Commission européenne, 1960-2004." In Industrie et politique en Europe occidentale et aux Etats-Unis (XIXe-XXe sicèles), edited by Dominique Barjot, Olivier Dard, Jean Garrigues, Didier Musiedlak, and Eric Anceau, 225-42. Paris: Presses universitaires Paris Sorbonne, 2006.

_ _ "Le rôle de la Communauté Européenne du Charbon et de l'Acier dans le développement des politiques de reconversion industrielle et d'essor économique regional." In Strukturwandel aus vergleichender regionaler Perspektive nach 1945: Ruhrgebiet und Nord/Pas-de-Calais, in Mitteilungsblatt des Instituts für soziale Bewegungen, 30 edited by François Berger, Jean-François Eck, Peter Friedemann, and Karl Lauschke, 33-42. Bochum, 2003.

- "Space Construction as Mental Process: Heavy Industrial Regions in Comparative Perspective.” In Raumbildung als mentaler Prozess: Schwerindustrielle Ballungsregionen im Vergleich, edited by Tenfelde Klaus, in Mitteilungsblatt des Instituts für soziale Bewegungen, 39 (2008): 99-112.

- Histoire économique et sociale de la construction européennes (Peter Lang Collection Europe plurielle-Multiple Europes). Bruxelles: P.I.E.-Peter Lang, 2008.

Madurowicz-Urbanska, Helena. "Remarques sur la méthodologie des régions économiques et leurs valeurs épistémologiques." Studia Historiae Oeconomicae 15 (1980, 1981): 87-93.

- "Aspects of micro- and macroanalysis in hitorical socio-economic regionalization." Studia Historiae Oeconomicae 13 (1978): 26-39.

___ "Remarques sur la méthodologie des régions économiques et leurs valeurs épistémologiques." Studia Historiae Oeconomicae 15 (1980): 87-93.

Merenne-Schoumaker, Bernadette. La localisation des industries. Paris: Nathan, 1991.

Michel, Joël. "Le mouvement ouvrier chez les mineurs d'Europe occidentale (Grande-Bretagne, Belgique, France, Allemagne). Etude comparative des années 1880 à 1914.” PhD diss., Université de Lyon II, 1987.

Mirri, Mario. "Formazione di una regione economica. Ipotesi sulla Toscana, sul Veneto, sulla Lombardia." Studi veneziani XI (1986): 47-59.

Ohlin, Goran. "Reviewed work(s): Industrial Growth and Population Change: A Regional Study of the Coalfield Areas of Northwest Europe in the Later Nineteenth Century by E. A. Wrigley." The Journal of Economic History 22 (1962): 416-9.

Pollard, Sidney, ed. Region und Industrialisierung. Studien zur Rolle der Region in der Wirtschaftsgechichte der letzten zwei Jahrhunderte. Göttingen: Vandenhoeck \& Ruprecht, 1980.

—. Peaceful conquest. The industrialization of Europe, 1760-1970. Oxford, 1981. 
Poussou, Jean-Pierre, and Lottin Alain, eds. Naissance et développement des villes minières en Europe, Artois Presses Université, Collection "Histoire." Arras, 2004.

Pyke, Frank, Giacomo Becattini, and Werner Sengenberger, eds. Distretti industriali e cooperazione fra imprese in Italia. Firenze: Banca Toscana, 1991.

Quévit, Michel. La Wallonie, l'indispensable autonomie. Paris: Editions Entente, 1982. Les causes du déclin wallon. Bruxelles: EVO, 1978.

Sabel, Charles F. "La riscoperta delle economie regionali." Meridiana 3 (1988): 13-71.

Schirmann, Sylvain. "La CFTD face aux reconversions industrielles de 1964 à 1978." In La reconversion des bassins charbonniers. Une comparaison interrégionale entre la Ruhr et le Nord/Pas-de-Calais, edited by Jean-François Eck, Peter Friedemann, and Karl Lauschke. Revue du Nord, hors série, 223-33. Collection Histoire no. 21, Lille, 2006.

Steinberg, Heinz Günter. "Das Ruhrgebiet im 19. und 20. Jahrhundert. Ein Verdichtungsraum im Wandel.” In Selbstverlag der Geographischen Kommission für Westfalen. Münster: 1985.

Subra, Philippe. "La reconversion des régions industrielles, une approche géopolitique: l'exemple du Valenciennois." In La reconversion des bassins charbonniers. Une comparaison interrégionale entre la Ruhr et le Nord/Pas-de-Calais, edited by Jean-François Eck, Peter Friedemann, and Karl Lauschke, Revue du Nord, hors série, 125-37. Collection Histoire no. 21, Lille, 2006.

Tenfelde, Klaus, ed. "Raumbildung als mentaler Prozess: Schwerindustrielle Ballungsregionen im Vergleich.” Mitteilungsblatt des Instituts für soziale Bewegungen. 39 (2008).

Weiller, J. "La politique française de conversion, l'Europe des Six et ses engagements internationaux: l'exemple français." Problèmes de conversion économique. Analyses théoriques et études appliquées. Actes du Quatrième Colloque de l'Association de Science Régionale de Langue Française, Liège, mai 1964, Paris, M.-Th. Génin, 1965, pp. 210-211.

Willaert, Emilie. "Les activités de la BEI dans l'Europe des Six (1958-1972)." In La banque de l'Union européenne. La BEI, 1958-2008, edited by Eric Bussière, Michel Dumoulin, and Emilie Willaert, 51-70. Luxembourg: 2008.

Wodz, Jacek. Haute-Silésie. L'espace déchiré. Spécificité d'une région fort industrialisée. Katowice, 1990.

Wrigley, Anthony E. Industrial Growth and Population Change. A Regional Study of the Coalfield Areas of North-West Europe in the Late Nineteenth Century. New York: Cambridge University Press, 1961.

Zuindeau, Bertrand. "Région Nord Pas de Calais, 2004, Atlas régional du développement durable Nord - Pas de Calais, La Tour d'Aigues, éditions de l'aube." Développement durable et territoire, Publications de 2004, mis en ligne le 20 novembre 2004. http://developpement durable.revues.org/document1245.html. 